\title{
A sustainable urban tourism indicator in Malaysia
}

\author{
M. K. Razali \& H. N. Ismail \\ Faculty of Built Environment, Universiti Teknologi Malaysia, Malaysia
}

\begin{abstract}
This paper presents a critical review on indicators for measuring sustainable urban tourism development in Malaysia. It has been debated that the contribution of urban tourism in the economy and local community's development are difficult to be determined due to the multiple discipline that clouds the existence of urban tourism as an independent sector. Arguably, these indicators failed to measure the level of achievement for urban tourism activities, and the economic terms are less justified. Since the concept of sustainable tourism is introduced, the role of indicator is increasingly important in measuring economic and social advantages, thus the development of the city also needs to be monitored with suitable indicator. The idea is to assess and monitor changes in urban economies for tracking the progress towards sustainable development. Therefore, the center of debate in developing urban tourism indicators are (1) to identify and measure the entire range of interrelated environmental, social and economic impacts in tourism development, and (2) to obtain accurate information for responsible decision. Several approaches have been made in the context of Malaysia although the indicators are not directly related to the perspective of urban tourism, such as Malaysian Quality of Life Index (MQLI) and Malaysian Urban Indicators Network (MURNINet). For example, MURNINet identified heritage and tourism as a sub-component of the indicator. As there is need to improve these indicators, situational analysis based on literature review in this paper will highlight the use of existing sustainable indicators and their relevancy to urban tourism development and economy.
\end{abstract}

Keywords: sustainable tourism, urban tourism, urban development, indicator. 


\section{Introduction}

Sustainable development has become a common buzzword in the developmental studies since the industrial revolution in the $19^{\text {th }}$ century, while sustainable tourism term has been widely used since two decades ago [1]. There have been many studies and researchers on sustainable development in general, as well as in specific industries around the world. In tourism industry, sustainable development started to grow after the 1980s (Page and Hall [2]). Numerous authors have contributed in providing studies on different perspectives and in different regions. The common purpose for countries to sustain the tourism is to host tourists [3] and protect the environment [4].

Tourism brings economic benefits, while preservation of natural environment has been the global main concern. The urban development in Malaysia started soon after the government proposed its Vision 2020 and they consistently executed the Master Plan [5]. The vision is to develop country's economic and social condition, and bring forward the vision to become a developed nation by year 2020. For this purpose, the government has been implementing many strategies alongside the Master Plan, and tourism is one of the main concerns for the country. In this perspective, Malaysian government has developed indicators that monitor and evaluate the progress of sustainable tourism in Malaysia. This study brings forward a critical review to highlight indicators for measuring sustainable urban tourism development in Malaysia.

\section{Literature review}

This section presents the review of previous research journal articles that discussed sustainable development, urban development, sustainable urban tourism and related concepts regarding sustainable development, with the focus on urban tourism.

\subsection{Sustainable development}

The concept of sustainable development was introduced in 1987 by the Brundtland Commission. It is defined as the development that meets the need of the present without compromising the ability of future generations to meet their own needs (Haghshenas and Vaziri [6]). Sustainable development consists of three elements, namely environmental, economic and social development [6]. The concept of sustainable development was introduced to minimize the impact of development especially in environmental issues and helped to reduce poverty among poor countries (WCED [7]). Thus, there will be positive impact towards development when the suggestion from WCED is applied.

\subsection{Sustainable development indicator}

The need of sustainable development indicator (SDI) was raised during World Summit in Rio 1992, where the action plan Agenda 21 was used to formulate 
indicators necessary for monitoring sustainable development [8]. SDI has been used to measure the growth and impact of development in a country. An indicator can be described as something that helps us to understand the previous and current position and future state or position [9]. There are many functions of indicators, such as helping policy makers to make better decision and to execute effective actions [10]. Regardless of being a developing country, Malaysia has been very attentive in applying the concept of sustainable development whenever needed. Othman and Pereira [11] believed that the government first introduced the principles of sustainable development in the Third Malaysia Plan (19761980), and later in the Eighth Malaysia Plan (2001-2005), where the government focused on environmental issues.

\subsection{Urban development}

The Concise Oxford Dictionary [12] stated that the word "development" represents growth, evaluation, and stage of advancement. Urban development denotes the growth or transformation of the city or town area. In addition, Allan [13] has provided three criteria while defining the word "development", which are vision, historical process and action. Since Malaysia became independent in 1957, there is a lot of development made until today, notably in terms of the transformation of economic growth, increasing in employment, and vibrancy in foreign exchange, where these factors give impact on the nation's development process [14]. However, the growth in urban development also contributes to negative impacts, such as environmental pollution and traffic problem [15]. As a result, a sustainable development report, "Our Common Future" was presented in Bruntland by the World Commission on Environment and Development [7], where the concept of sustainable development was introduced in urban development. Furthermore, Agenda 21 has been introduced during Earth Summit in Rio de Janeiro in 1992, which provided suggestions for action or changing the traditional patterns of development to achieve sustainability, especially in the urban area [16].

\subsection{Urban sustainability}

Urban sustainability is a combination of the words "urban" and "sustainable". Previously, the concept of sustainability focused mainly on rural area or area with environmental sensitivity (Barke and Newton [17]). Urban or city is the place with an increasing statistical proportion of population within the area [11]. Sustainability can be defined as meeting the needs of a community, i.e. physical, social, economic and environmental, without limiting the capacity of future generation to meet their own needs (Pierce et al. [18]). Furthermore, the concept of urban sustainability strategies are helpful in increasing the urban efficiency in consumption and in reducing negative externalities (Finco and Nijkamp [19]). In Malaysia, the federal government, state government and local authorities cooperate together during the planning and development of an urban area. 


\subsection{Urban tourism}

Urban tourism can be defined as tourism within cities and towns [20]. Researchers [21] have mentioned that cities are places where various major facilities such as transport, hotel and event infrastructure are located. This means that urbanization is a contributor for the development of towns and cities where people live, work and shop [2]. In fact, during the development period, town or city tends to improve the living standards and the area becomes location for tourism activity that has the accommodation and entertainment function [2]. The development of urban tourism has increased in the late 1970s [2].

In the early 1980s, the research on urban tourism started to gain attention [2] Researchers [21] came up with five major factors that characterize cities as tourism destinations: (1) Major travel nodes that serve as gateways or transfer points to other destinations; (2) High populations which attract large numbers of tourists who are visiting friends and relatives; (3) Focal points for commerce, industry and finance; (4) Concentrations of services such as education, health and government administration center; and (5) Places that offer a wide variety of cultural, artistic and recreational experiences.

In Malaysia, most of the tourist attractions are located in the towns and cities, especially the capital cities in federal territories and states. In the early 1980s, the government introduced urban conservation in the development of urban area in several heritage cities such as Kuala Lumpur, Georgetown, Malacca and Kota Bahru (Ahmad [22]). It shows that cities became a tourism product, especially those with rich heritage and multicultural society, and the cities also became famous tourist destinations in Malaysia [22].

\subsection{Sustainable tourism development}

World Tourism Organization (WTO-OMT) has practiced the concept of sustainable development in tourism. Sustainable tourism development (STD) is a process of meeting the needs of present tourist and host region, whilst protecting and enhancing opportunities for the future (Cernat and Gourdon [3]). However, tourism activities have caused environmental and socioeconomic problems [4]. For this purpose, sustainable tourism principles can help planners to make strategic planning to overcome the problems.

Furthermore, WTO is actively promoting the concept of sustainable tourism among its members. WTO has introduced and developed sustainable tourism indicators to measure and monitors the progress of sustainable tourism. WTO defines sustainable tourism indicators (STI) as "the set of measures that provides the information for better understanding of the link between the impact of tourism on the cultural and natural setting that takes place, and on the cultural and natural setting in which this take place, and on which it is strongly dependent" [23]. Sustainable tourism indicators have three basic functions: (1) the formulation of general action plans at a regional level; (2) the definition of short-term strategies for destinations; and (3) the establishment of destination benchmarking practices [23]. In addition, WTO has compiled a database of 
indicators in its guidebook as a reference to help policy makers in the planning of sustainable tourism [4].

\subsection{Sustainable tourism indicator}

The purpose of the development of indicator is to assess and monitor changes or progress of sustainable development (Roberts [24]). Indicators quantify change, identify processes and provide a framework for setting targets and monitoring performance [25]. Thus, indicator is a tool to measure the performance or tracks the progress of development. In addition, indicator has also becomes a tool for communication to promote information exchange regarding the issues (White et al. [25]). Nevertheless, it is very important to develop indicator as the tool to track the progress or monitor the performance, as well as the impact towards the development of sustainable tourism. Previous research have listed several criteria of good indicators, such as measurable, sensitive, economically viable, acceptable and accessible, useable and easily interpreted, reliable, verifiable and replicable, participative process, specific, timely, transparency, relevant and scientifically well-founded [25].

\subsection{Sustainable urban tourism}

The concept of sustainable urban tourism is relatively new in the area of sustainable tourism. Previously, urban tourism did not consider sustainable issues until the World Tourism Organization introduced the indicator of sustainable development for tourism destinations (WTO [26]). Since then, most of the researches on sustainable tourism have focused on rural tourism and communitybased tourism [17]. Nevertheless, it is very important to bring the concept of sustainable tourism to the urban area for long-term sustainability.

\subsection{Sustainable urban tourism indicator}

Indicator is very important to measure the progress of the development in sustainable urban tourism. Indicator can be define as "something that helps you to understand where you are, which way you are going and how far you are from where you want to be" [9]. A previous historical indicator developed in the mid1960s denotes that William Ogburn developed statistical measurement to monitor changes in social trends [27]. This means that indicator can be used as a tool to measure the existing issues, signals of problems, measures of risk and potential need for action, and as a means to identify and measure the results of our actions [26].

In the concept of urban tourism, it is very important to measure the current situation of the development of urban tourism area, which are the major attractions in the country. The results from the indicator can help developers in planning sustainable tourism, particularly for tourism destinations. There are three important dimensions in sustainable development, which are economic, social, and environment [28]. 


\subsection{Urban development in Malaysia}

Malaysia is located in Southeast Asia and consists of eleven states and three federal territories [29]. The country became independent in 1957, and since then the country has started its development. The government invested a lot of money in developing infrastructures and executed different projects to provide better facilities to the citizens by implementing the properly planned National Master Plan [5].

Previously, the Malaysian government focused on the development of infrastructure, such as airport, and accommodation in and around the capital city of Malaysia, Kuala Lumpur Ismail, Baum, and Kokranikkal [30]. Later, the government realized that Malaysia could become a major tourism destination in the world as the country received 25.03 million tourists and received RM 60.6 billion from tourism activity. The tourism sector in Malaysia has contributed in providing the second largest foreign exchange earnings and helped the country to strengthen the economy [31]. In addition, there are a lot of benefits from the development of tourism industry towards the community, such generating income, taxes, currency and jobs (Choi and Sirakaya [27]).

\section{Initiatives of the sustainable development indicator in Malaysia}

The concept of sustainable development in Malaysia started with the Malaysia Plan since 1970, which includes both long and short term plans [11]. At the beginning of sustainable concept, the government focused on environmental issues. Moreover, the researcher [32] stated the need for the environmental database and information systems in the Seventh Malaysia Plan towards sustainable development. Thus, indicators have been developed for monitoring and evaluating the progress of sustainable development in Malaysia.

In Malaysia, the development of an indicator was started in 1995 by the Institute for Environmental and Development (LESTARI), Universiti Kebangsaan Malaysia [33]. The indicators for sustainable development have been formed by federal government agencies, state governments and nongovernmental organization (NGO), and Malaysia has several sustainable development indicators. Table 1 shows the summary of sustainable development indicators in Malaysia.

From the literature review, there are eleven (11) indicators established in Malaysia. The first indicator was developed in 1997 by Department of Health, Municipal Council of Kuching, Johor Bahru and Malacca. The latest indicator was developed in 2013, namely MURNInets, which is a rebrand of Malaysian Urban Rural National Indicator Network. The selected indicators are used as the benchmark for the present indicators implemented at all levels of planning in the country, for example National Physical Plan (NPP), National Urbanisation Policies (NUP), and Sustainability Assessment (SA) [34]. It shows that the Malaysian government has taken the initiatives to develop the indicator as the benchmark or as the tool in developing the country. 
Table 1: Summary of the sustainable development indicator in Malaysia.

\begin{tabular}{|c|c|c|c|}
\hline Year & Authority/developer & Indicator & Summary \\
\hline 2013 & $\begin{array}{l}\text { Federal Department } \\
\text { of Town and Country } \\
\text { Planning, Peninsular } \\
\text { Malaysia }\end{array}$ & \begin{tabular}{l|} 
Malaysian Urban \\
Rural National \\
Indicators Network \\
on Sustainable \\
Development \\
(MURNInets)
\end{tabular} & $\begin{array}{l}\text { The new MURNInets } \\
\text { consists of } 36 \text { sets under } 21 \\
\text { themes and } 6 \text { dimensions. } \\
\text { The goal of MURNInets is } \\
\text { to establish sustainable } \\
\text { urban environment by } \\
\text { improving the quality of } \\
\text { housing and services. }\end{array}$ \\
\hline 2009 & $\begin{array}{l}\text { Malaysian Institute of } \\
\text { Architects (PAM) }\end{array}$ & $\begin{array}{l}\text { Green Builiding } \\
\text { Index (GBI), } \\
\text { Malaysia }\end{array}$ & $\begin{array}{l}\text { GBI contains six different } \\
\text { rubric aspects such as } \\
\text { energy efficiency, indoor } \\
\text { environmental quality, } \\
\text { sustainable site planning } \\
\text { and management, material } \\
\text { and resources, water } \\
\text { efficiency and innovation. }\end{array}$ \\
\hline 2004 & $\begin{array}{l}\text { Federal Department } \\
\text { of Town and Country } \\
\text { Planning, Peninsular } \\
\text { Malaysia }\end{array}$ & $\begin{array}{l}\text { Malaysian Urban } \\
\text { Indicators Network } \\
\text { (MURNInet) }\end{array}$ & $\begin{array}{l}\text { MURNInet consists of fifty } \\
\text { five (55) indicators to } \\
\text { evaluate the sustainability } \\
\text { of a city and region through } \\
\text { eleven (11) planning } \\
\text { sectors. }\end{array}$ \\
\hline 2003 & $\begin{array}{l}\text { Federal Territory } \\
\text { Development and } \\
\text { Klang Valley } \\
\text { Planning Division, } \\
\text { Prime Minister's } \\
\text { Department }\end{array}$ & $\begin{array}{l}\text { Klang Valley } \\
\text { Regional } \\
\text { Sustainable } \\
\text { Quality of Life } \\
\text { Index ( } \\
\text { KVRSQLI) }\end{array}$ & $\begin{array}{l}\text { The goal of KVRSQLI is to } \\
\text { develop stress ratio for the } \\
\text { allocation of resources } \\
\text { within Klang Valley. The } \\
\text { formulation for the } \\
\text { indicator is completed and } \\
\text { it focused on regional } \\
\text { planning. }\end{array}$ \\
\hline 2001 & $\begin{array}{l}\text { Sarawak Natural } \\
\text { Resources Board }\end{array}$ & $\begin{array}{l}\text { Sustainable Urban } \\
\text { Development } \\
\text { Indicators (SUDI) }\end{array}$ & $\begin{array}{l}\text { The goal of SUDI is to } \\
\text { assess the improvement in } \\
\text { urban issues such as water } \\
\text { quality and waste } \\
\text { management by using } \\
\text { Environmental } \\
\text { Management Systems } \\
\text { (EMS) as the guiding } \\
\text { framework. }\end{array}$ \\
\hline
\end{tabular}


Table 1: Continued.

\begin{tabular}{|c|c|c|c|}
\hline Year & Authority/developer & Indicator & Summary \\
\hline 1999 & $\begin{array}{l}\text { Economic Planning } \\
\text { Unit, } \\
\text { Prime Minister's } \\
\text { Department }\end{array}$ & $\begin{array}{l}\text { Malaysian Quality } \\
\text { of Life Indicator } \\
\text { (MQLI) }\end{array}$ & $\begin{array}{l}\text { The goal of MQLI is to } \\
\text { measure Malaysian success } \\
\text { beyond economic } \\
\text { achievement. MQLI } \\
\text { consists of fourteen (14) } \\
\text { theme indicators. }\end{array}$ \\
\hline 1998 & $\begin{array}{l}\text { Selangor State } \\
\text { Government }\end{array}$ & $\begin{array}{l}\text { Sustainable } \\
\text { Development } \\
\text { Indicators for the } \\
\text { State of Selangor } \\
\text { (SDIS) }\end{array}$ & $\begin{array}{l}\text { The main objective of } \\
\text { SDIS is to formulate } \\
\text { strategies and action plan } \\
\text { for implementing } \\
\text { development, and the } \\
\text { indicators used a 'fitness- } \\
\text { for-purpose' strategy as the } \\
\text { frameworks. There are } 30 \\
\text { sets of indicators to } \\
\text { measure sustainable } \\
\text { development, which are } \\
\text { divided into four } \\
\text { sustainability classes such } \\
\text { as economy, environment, } \\
\text { natural resource and social. }\end{array}$ \\
\hline 1998 & $\begin{array}{l}\text { Environmental } \\
\text { Statistics Section, } \\
\text { Department of } \\
\text { Statistics Malaysia }\end{array}$ & $\begin{array}{l}\text { Compendium of } \\
\text { Environment } \\
\text { Statistics (CES) }\end{array}$ & $\begin{array}{l}\text { The focus of CES is on the } \\
\text { integration of socio- } \\
\text { economic information with } \\
\text { environmental parameters } \\
\text { and it is based on the } \\
\text { approach of Pressure-State- } \\
\text { Response (PSR) model. }\end{array}$ \\
\hline 1997 & $\begin{array}{l}\text { Department of } \\
\text { Health, } \\
\text { Municipal Council of } \\
\text { Kuching, Johor } \\
\text { Bharu, and Malacca }\end{array}$ & $\begin{array}{l}\text { Healthy Cities } \\
\text { Indicators (HCI) }\end{array}$ & $\begin{array}{l}\text { The goal of HCI is to } \\
\text { create social and physical } \\
\text { environment for healthy } \\
\text { urban population and it is } \\
\text { developed based on World } \\
\text { Health Organisation } \\
\text { framework, however the } \\
\text { development is still at an } \\
\text { early stage. }\end{array}$ \\
\hline
\end{tabular}


Table 1: Continued.

\begin{tabular}{|c|l|l|l|}
\hline Year & Authority/developer & \multicolumn{1}{c|}{ Indicator } & \multicolumn{1}{c|}{ Summary } \\
\hline 1997 & $\begin{array}{l}\text { Penang State } \\
\text { Government }\end{array}$ & $\begin{array}{l}\text { Sustainable } \\
\text { Penang } \\
\text { Initiative(SPI), } \\
\text { Penang Report } \\
\text { Card (PRC) }\end{array}$ & $\begin{array}{l}\text { SPI has identified 40 } \\
\text { indicators which represent } \\
\text { the environment, } \\
\text { community, culture and } \\
\text { public participation, and } \\
\text { then People Report Card } \\
\text { (PRC) is produced. }\end{array}$ \\
\hline 1997 & $\begin{array}{l}\text { Environment and } \\
\text { Natural Resource } \\
\text { Section of the } \\
\text { Economic Planning } \\
\text { Unit, } \\
\text { Prime Minister's } \\
\text { Department }\end{array}$ & $\begin{array}{l}\text { Malaysian } \\
\text { Sustainable } \\
\text { Development } \\
\text { Indicators (MSDI) }\end{array}$ & $\begin{array}{l}\text { The goal of MSDI is to } \\
\text { develop a national system } \\
\text { for tracking progress } \\
\text { towards sustainability and } \\
\text { aims to integrate } \\
\text { sustainability elements into } \\
\text { national level development } \\
\text { planning. However, it is } \\
\text { still under the identification } \\
\text { stage. }\end{array}$ \\
\hline
\end{tabular}

In the tourism industry, ecotourism has gained more attention in Malaysia compared to other types of tourism such urban tourism, rural tourism and others. Following the development of ecotourism in Malaysia, the Ministry of Tourism and Culture (previously the Ministry of Culture, Arts and Tourism) developed the National Ecotourism Plan in 1996 to assist the government in developing the potential ecotourism [35]. The plan also indicates the benchmark or indicator for successful ecotourism sites, which should be followed by the tourism stakeholder. Moreover, tourism sector only becomes a sub-theme in the previous developing indicators such as MURNInet and Malaysian Quality of Life Index (MQLI) [33]. It shows that tourism plays an important role in urban development. Apart from that, the development of indicator is very important in dealing with environmental issue such as Compendium of Environment Statistics (CES) that is used as a tool to monitor pollution, depletion and degradation of environmental quality. It is very important because Malaysia has a lot of natural resources as tourist attractions. In addition, Malaysia is one of the 12 megadiversity countries in the world that accepts the importance of preserving its social, environmental and cultural wealth heritage [36].

\section{Discussion and conclusion}

The Malaysian government has been taking action in developing sustainable development indicator (SDI). Table 1 shows the list of sustainable development indicators in Malaysia since 1997 until 2013. Malaysia has started the efforts in sustainability development since 1970 as stated in the Malaysia Plan [11]. 
However, the development of sustainable indicator started later in 1995 by Institute for Environmental and Development (LESTARI), Universiti Kebangsaan Malaysia [35].

The development of indicators in Malaysia was carried out by federal government, state government and non-governmental organization, where the indicators have different objectives or goals. By referring to Table 1, some indicators are just at the early stages, such as Healthy Cities Indicator (HCI) and Malaysian Sustainable Development Indicators (MSDI) (Hezri [37]).

Most of the indicators measured the development in urban or city areas, for example Malaysian Urban Indicator Network (MURNInet) and Malaysian Quality of Life Index (MQLI). The early development indicator only focused on environment and social issues. For that reason, Malaysian Statistic Department has developed the Compendium of Environment Statistics (CES) indicator that focuses on environmental issues, such as depletion of natural resources and neglect of new scarcities, and degradation of environment quality [36]. Also, a professional institute such as the Malaysian Institute of Architects (PAM) has developed the Green Building Index Malaysia with the objective to implement sustainability in the development plan [38].

In 2013, the Federal Department of Town and Country Planning, Peninsular Malaysia had previously reviewed MURNInet and rebranded the indicator as Malaysian Urban Rural National Indicators Network on Sustainable Development. The objective of MURNInets is to establish sustainable urban environment by improving the quality of housing and services. There are some issues emerging from previous indicators such as the lack of local authority's participation and the choice of indicators' characteristics needs to be reviewed by the department. In addition, MURNInets have six dimensions which include competitive economy, sustainable environmental quality, sustainable community, optimum use of land and natural resources, efficient infrastructure and transport, and effective governance [33]. In context of sustainable tourism, there is no specific indicator to measure sustainable development of tourism in Malaysia. The tourism sector is only a sub-theme indicator in current sustainable development indicator, such as Malaysian Urban Indicator Network (MURNInet), Malaysian Quality of Life Index (MQLI) and Compendium of Environment Statistics (CES).

This has created difficulty in measuring the level of sustainable development and contribution of tourism in Malaysia. In addition, current indicator has failed to measure the contribution of urban tourism towards the economy and local communities. As a conclusion, the issues arise from current indicators are very important to develop indicators for sustainable urban to assess and monitor changes in urban economies, as well as to track the progress of sustainable development. The development of suitable indicator, especially in urban tourism, will give a lot of information regarding current status of sustainable concept in urban development. 


\section{References}

[1] Buckley, R., Sustainable Tourism: Research And Reality. Annals of Tourism Research, 39(2), 528-546, 2012

[2] Page Stephen J and Hall C Michael, Managing Urban Tourism, Prentice Hall, 15-17, 2003

[3] Cernat, L. \& Gourdon, J., Paths To Success: Benchmarking Cross-Country Sustainable Tourism. Tourism Management, 33(5), 1044-1056, 2012

[4] Tanguay, G. A., Rajaonson, J., \& Therrien, M.C,Sustainable Tourism Indicators: Selection Criteria For Policy Implementation And Scientific Recognition. Journal Of Sustainable Tourism, 1-18, 2012

[5] The Malaysia Plan Retrieve online www.pmo.gov.my

[6] Haghshenas, H. \& Vaziri, M., Urban Sustainable Transportation Indicators For Global Comparison. Ecological Indicators, 15(1), 115-121, 2012

[7] WCED, Our Common Future. Oslo. 1987

[8] Hak, T., Kovanda, J., \& Weinzettel, J., A Method To Assess The Relevance Of Sustainability Indicators: Application To The Indicator Set Of The Czech Republic's Sustainable Development Strategy. Ecological Indicators, 17, 46-57, 2012

[9] Miller, G., The Development Of Indicators For Sustainable Tourism: Results Of A Delphi Survey Of Tourism Researchers. Tourism Management, 22(4), 351-362, 2001

[10] Nations U. Indicators Of Sustainable Development: Guidelines And Methodologies Indicators Of Sustainable Development, 2007

[11] Othman, A., \& Pereira, J. J., Sustainable Development Indicators Providing Environmental Statistics For National Reporting. Proc. of the 14th Conference Of Commonwealth Statisticians, Cape Town, 1-13, 2005

[12] Haget, S.,Barriers For Tourism Sustainability In Destination By Sylvain Haget. Bournemouth University, 2009

[13] Allan, Meanings and Views of Development. Oxford: Oxford University Press, 2000

[14] Nunkoo, R., \& Smith, S. L. J. Political economy of tourism: Trust in government actors, political support, and their determinants. Tourism Management, 36, 120-132, 2013

[15] Hugentobler, M., \& Brändle-Ströh, M., Sustainable Urban Development: A Conceptual Framework And Its Application. Journal of Urban Technology, 4(2), 85-99, 1997

[16] Kamarudin Ngah, Jamaludin Mustafa, Zaherawati Zakaria, N. N. and M. Z. H. M. S, Formulation Of Agenda 21 Process Indicators For Malaysia. Journal Of Management And Sustainability, 1(1), 82-89. 2011

[17] Barke M. \& Newton M, Promoting Sustainable Tourism is an Urban Context, Research Development in Malaga City, Andalusia, Journal of Sustainable Tourism, Vol 3 (3) 115-134, 1995

[18] Pierce, J. C., Budd, W. W., \& Lovrich, N. P., Resilience And Sustainability In Us Urban Areas. Environmental Politics, 20(4), 566-584, 2011 
[19] Finco, A. \& Nijkamp, P., Pathways To Urban Sustainability. Journal Of Environmental Policy \& Planning, 37-41, 2001

[20] Selby Martin, Understanding Urban Tourism, Image, Culture \& Experience, I.B. Tauris, 11-12, 2004

[21] Ismail, H., \& Baum, T. O. M, Anatolia: An International Journal Of Tourism And Urban Tourism In Developing Countries: In The Case Of Melaka ( Malacca ) City, Malaysia, 211-233, 2006

[22] Ahmad, G. Urban Tourism In Malaysia : Heritage Cities Of Georgetown, Malacca And Kota Bharu. Proc. of the 2nd. International Seminar On European Architecture And Town Planning Outside Europe (Dutch Period). Malacca 1-16, 1998

[23] Lozano-Oyola, M., Blancas, F. J., González, M., \& Caballero, R., Sustainable Tourism Indicators As Planning Tools In Cultural Destinations. Ecological Indicators, 18, 659-675, 2012

[24] Roberts, S., Sustainability Indicators For Small Tourism Enterprises - An Exploratory Perspective, 16(5), 2008

[25] White, V., Mccrum, G., Blackstock, K. L., \& Scott, A., Indicators and Sustainable Tourism : Literature Review, 2006

[26] WTO, Indicators Of Sustainable Development For Tourism Destinations A Guidebook. Madrid: World Tourism Organization, Madrid, 2004

[27] Choi, H. C., \& Sirakaya, E., Sustainability Indicators For Managing Community Tourism. Tourism Management, 27(6), 1274-1289, 2006

[28] Saadatian, O., Haw, L. C., Mat, S. Bin, \& Sopian, K.. Perspective Of Sustainable Development In Malaysia. International Journal Of Energy And Environment, 6(2), 260-267, 2012

[29] About Malaysia In Brief Online www.tourismmalaysia.gov.my

[30] Ismail, H., Baum, T., \& Kokranikkal, J, Urban Tourism In Developing Countries: A Case Of Malaysia. Proc of the "Urban Tourism - Mapping The Future" Ttra Europe Conference, Glasgow, 1-12, 2003

[31] Hafiz, M., Hanafiah, M., Fauzi, M., \& Harun, M.,Tourism Demand In Malaysia : A Cross-Sectional Pool Time-Series Analysis, 1(1), 2010

[32] Hasan, M. N. H., Indicators Of Sustainable Development: The Malaysian Perspective. In Proceedings of Regional Dialogue on Geo-Indicators for Sustainable Development. Institute for Environment and Development (Lestari), Geological Survey Department of Malaysia, and The Commission on Geological Sciences for Environmental Planning, 1-16, 1998

[33] Hasan, M. N., \& Adnan, A. H., Sustainable Development Indicator Initiatives In Malaysia - Novel Approaches And Viable Frameworks. Lestari UKM, 2004

[34] Shamsaini Shamsuddin \& Azmizam Abdul Rashid, Malaysian Urban Rural National Indicators Network On Sustainable Development (Murninets). Proc of the 43rd Annual Conference Of The Urban Affairs Association, San Francisco California, 1-13, 2013 
[35] Hassanal, A., Success Indicators Development for Ecotourism Ventures. In Akepts 1st Annual Young Researchers Conference And Exhibition. Kuala Lumpur, 2011

[36] Wahid, N. A., Amran, A., Haat, H. C., \& Abustan, I., Towards A Sustainable Tourism Management In, 301-312, 1998

[37] Hezri, A. A., Sustainability Indicator System And Policy Processes In Malaysia: A Framework For Utilisation And Learning. Journal of Environmental Management, 73, 357-371, 2004

[38] Mun, T. L. The Development of GBI

Malaysia ( GBI ). PAM/ACEM, 1-8, 2009 